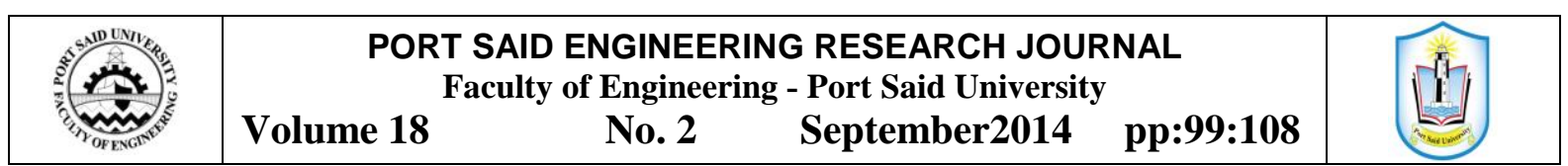

\title{
EXPERIMENTAL INVESTIGATION OF STRENGTHENED SHORT CONCRETE COLUMNS
}

\author{
KHALED MOHAMED MAHMOUD ${ }^{1, *}$, HASSAN MOHAMED HASSAN IBRAHIM ${ }^{2}$, KAMAL GAD SHAROBEM $^{3}$
}

\begin{abstract}
Reinforced concrete (RC) columns in buildings often need strengthening either due to defects in the columns themselves, having to support higher loads than those foreseen in the initial design of the structure, or as the result of ageing or accidental damage. There are many methods of columns strengthening such as jackets with their different types. Jackets are often performed at construction sites by primitive methods, without taking into consideration the correct design or the requirements which should be implemented. At this research, two methods of strengthening have been studied experimentally: concrete jacketing and steel cage. The experimental study consisted of twenty specimens of $800 \mathrm{~mm}$ height, $100 \times 100 \mathrm{~mm}$ cross section, and main reinforcement $4 \varnothing 6 \mathrm{~mm}$ with stirrups $7 \varnothing 4 \mathrm{~mm} / 800 \mathrm{~mm}$. The specimens were strengthened by concrete and steel jackets. From the results of obtained capacity and mode of failure, some modifications were implemented on jacket to improve the efficiency of jackets.
\end{abstract}

KEYWORD: RC columns, strengthening, concrete jacket, steel jacket.

\section{INTRODUCTION}

Behaviour of reinforced concrete columns strengthened with different types of jackets has been extensively studied [1-5]. The main function of jackets is to provide the core concrete of column with high confinement to help resisting axial loads. Confined concrete can be defined as the concrete restrained in the directions perpendicular to the applied stresses. The concrete becomes confined when the applied stresses approach the axial compressive strength, where the lateral strains remarkably increase due to progressive internal fracturing. When the concrete commences to increase in volume and bears out against the jacket, the jacket applies confining pressure to the concrete [6]. This research aimed to achieve the maximum efficiency of jackets by studying the factors and conditions which effected at jackets to select the optimum jacket for columns strengthening. It was studied the comparison between concrete jacket and steel jacket. Experimental investigations for jackets had been done to compare its results with theoretical results. So, this paper presents some equations for design jackets and conclusions of experimental results to

${ }^{1}$ Graduate student, Suez Canal Authority, Port Said, Egypt.

${ }^{2}$ Professor of concrete structures and the Chief Head of Civil Engineering Department at Port Said University, Port said,

${ }^{3}$ Professor of strength of materials and Vice President of Suez. Canal University for Community service and Environmental Development, Ismailia, Egypt. help structural engineers at columns strengthening process.

\section{EXPERIMENTAL PROGRAM}

The experimental program consists of twenty reinforced concrete specimens: four specimens of original column before strengthening, nine specimens of strengthened reinforced concrete column by concrete jacket, and seven specimens strengthened by steel jacket (cage). Table 1, 2, and 3 describes the columns' groups which are classified into six groups where each group consists of three samples as follow:

Table 1 Original column specimens

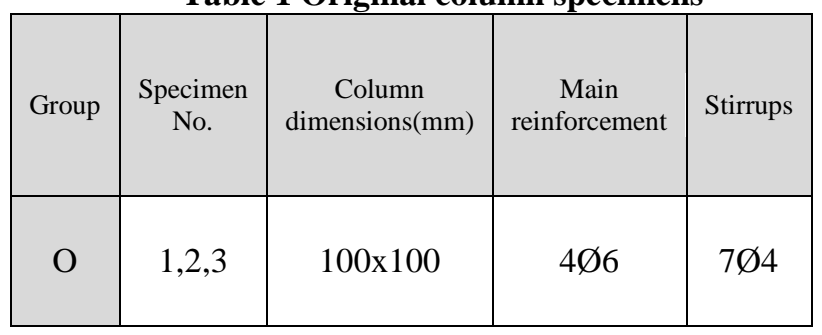


Table 2 Test specimens' parameter of concrete jacket

\begin{tabular}{|c|c|c|c|c|c|}
\hline Group & $\begin{array}{c}\text { Specimen } \\
\text { No. }\end{array}$ & $\begin{array}{c}\text { Column } \\
\text { dimensions } \\
\text { after } \\
\text { strengthenin } \\
\mathrm{g}(\mathrm{mm})\end{array}$ & $\begin{array}{c}\text { Jacket main } \\
\text { reinforcement }\end{array}$ & $\begin{array}{c}\text { Jacket } \\
\text { stirrups }\end{array}$ & Remark. \\
\hline A & $4,5,6$ & $150 \times 150$ & $4 \varnothing 6$ & $7 \varnothing 4$ & $\begin{array}{c}\text { Square } \\
\text { stirrups }\end{array}$ \\
\hline B & $7,8,9$ & $150 \times 150$ & $4 \varnothing 6$ & $9 \varnothing 4$ & $\begin{array}{c}\text { Square } \\
\text { stirrups }\end{array}$ \\
\hline C & $10,11,12$ & $150 \times 150$ & $4 \varnothing 6$ & $7 \varnothing 4$ & $\begin{array}{c}\text { Jacket height } \\
\text { shorter than } \\
\text { core by } \\
50 m m\end{array}$ \\
\hline
\end{tabular}

Table 3 Test specimens' parameter of steel jacket

\begin{tabular}{|c|c|c|c|c|c|c|}
\hline Group & $\begin{array}{c}\text { Specimen } \\
\text { No. }\end{array}$ & Core & $\begin{array}{c}\text { Corner } \\
\text { angles } \\
\text { size }(\mathrm{mm})\end{array}$ & $\begin{array}{c}\text { Stirrups } \\
\text { plates }(\mathrm{mm})\end{array}$ & $\begin{array}{l}\text { No. of } \\
\text { stirrups }\end{array}$ & Remark. \\
\hline D & $13,14,15$ & \multirow{2}{*}{$\begin{array}{c}\text { As } \\
\text { columns } \\
\text { at group } \\
\mathrm{O}\end{array}$} & $30 \times 30 \times 3$ & $\begin{array}{c}4 \text { plates } \\
100 \times 30 \times 3\end{array}$ & 6 & \\
\hline $\mathrm{E}$ & $16,17,18$ & & $30 \times 30 \times 3$ & $\begin{array}{c}4 \text { plates } \\
100 \times 30 \times 3\end{array}$ & 8 & \\
\hline
\end{tabular}

\subsection{Specimens Details:}

Details of specimens are indicated in Fig (1) as follow:

The tested columns were divided into six groups and every group presents a case study and consists of three specimens. The original specimen (core of strengthened column) has cross-section $100 \times 100$ $\mathrm{mm}$, main steel $4 \varnothing 6 \mathrm{~mm}$, and stirrups $7 \varnothing 4 \mathrm{~mm}$ as shown in Fig. (1a) named group (O).

The second is group (A) consists of three specimens, each specimen constitutes the original column (as shown in group $\mathrm{O}$ ) and was strengthened by concrete jacket consists of main steel $4 \varnothing 6 \mathrm{~mm}$, and square stirrups $7 \varnothing 4 \mathrm{~mm}$ and covered by concrete with thickness $2.5 \mathrm{~cm}$ at each side. The total cross-sections of the strengthened specimens are $150 x 150 \mathrm{~mm}$ as shown in Fig. (1b).

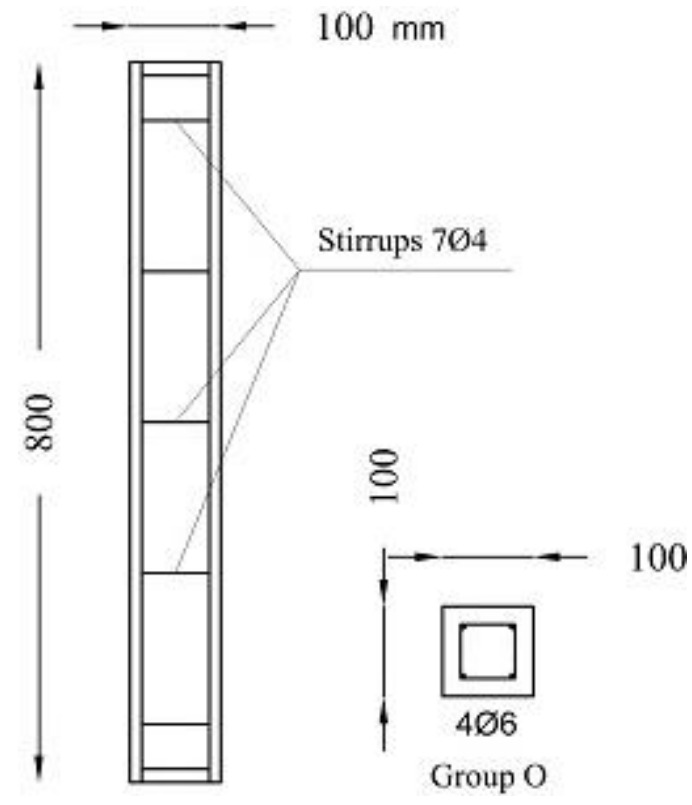

Fig.1a Specimens details of group (O) 


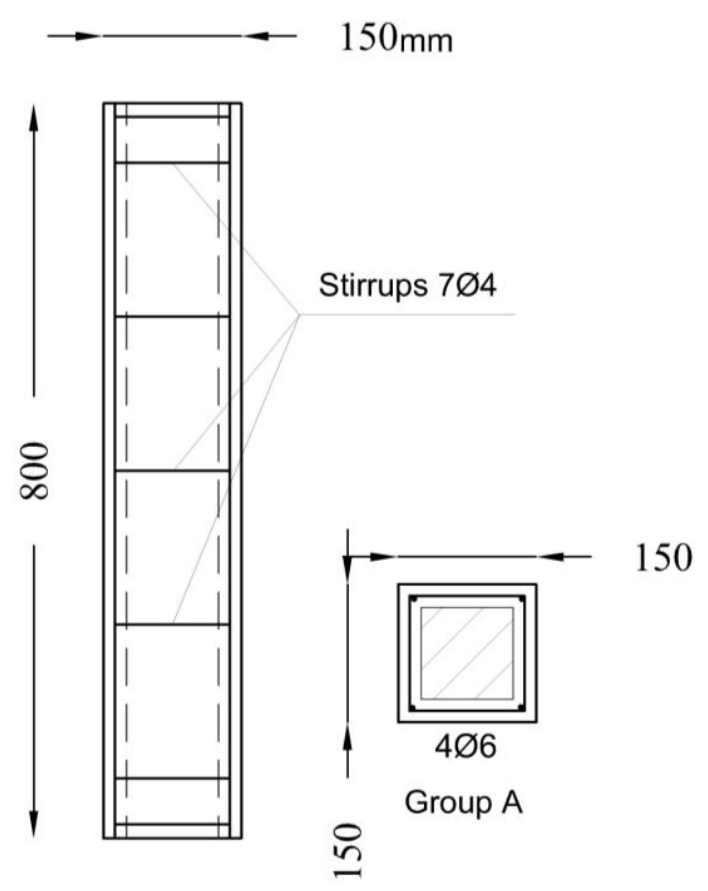

Fig.1b Specimens details of group (A)

The third is group (B) consists of three specimens, each specimen constitutes the original column (as shown in group $\mathrm{O}$ ) and was strengthened by concrete jacket consists of main steel $4 \varnothing 6 \mathrm{~mm}$, and square stirrups $9 \emptyset 4 \mathrm{~mm}$ and covered by concrete with thickness $2.5 \mathrm{~cm}$ at each side. The total crosssections of the strengthened specimens are $150 \times 150$ $\mathrm{mm}$ as shown in Fig. (1c).

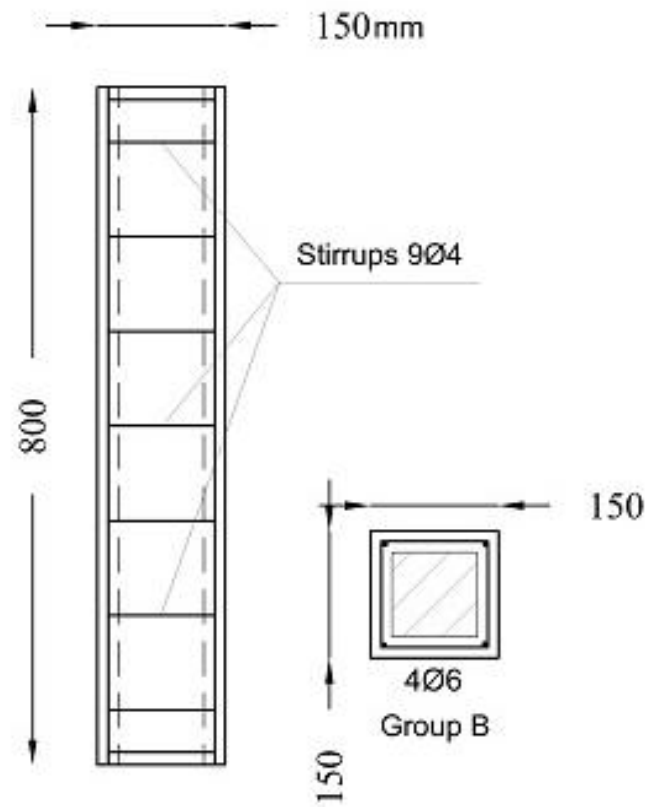

Fig.1c Specimens details of group (B)

The fourth is group (C) consists of three specimens, each specimen constitutes the original column (as shown in group $\mathrm{O}$ ) and was strengthened by concrete jacket consists of main steel $4 \varnothing 6 \mathrm{~mm}$, and square stirrups $7 \varnothing 4 \mathrm{~mm}$ and covered by concrete with thickness $2.5 \mathrm{~cm}$ at each side. The total cross-sections of the strengthened specimens are $150 \times 150 \mathrm{~mm}$ taken into consideration that the jacket height is shorter than the core by $50 \mathrm{~mm}$ as shown in Fig. (1d).



Fig.1d Specimens details of group (C)

The fifth is group (D) consists of three specimens, each specimen constitutes the original column (as shown in group O) and was strengthened by steel jacket consists from four vertical corner angles $30 \times 30 \times 3 \mathrm{~mm}$, and six horizontal Patten plates as stirrups welded to corner angles with dimensions 100x30x3 mm at each side as shown in Fig. (1e).

The sixth is group (E) consists of three specimens, each specimen constitutes the original column (as shown in group O) and was strengthened by steel jacket consists of four vertical corner angles $30 \times 30 \times 3 \mathrm{~mm}$, and eight horizontal Patten plates as stirrups welded to corner angles with dimensions 100x30x3 mm at each side as shown in Fig. (1f).

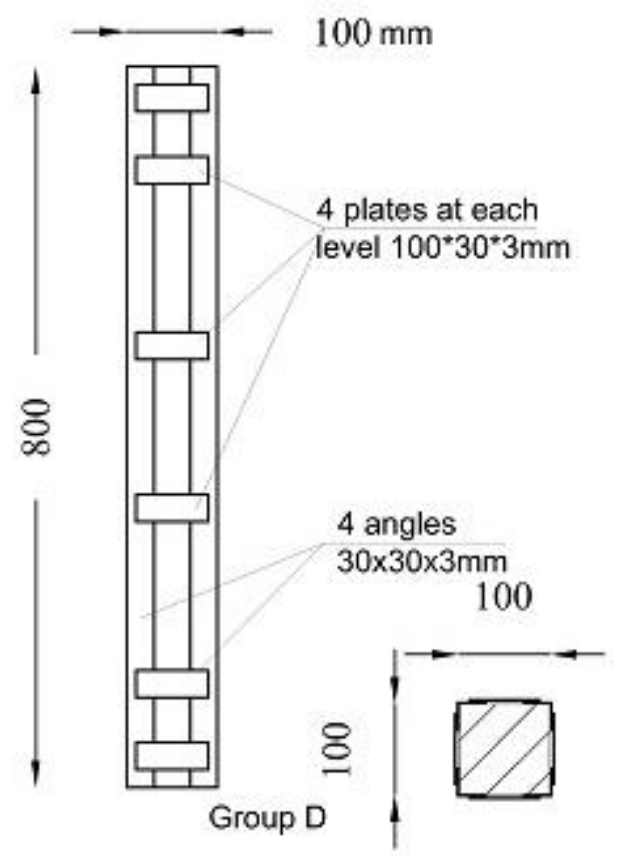


Fig.1e Specimens details of group (D)

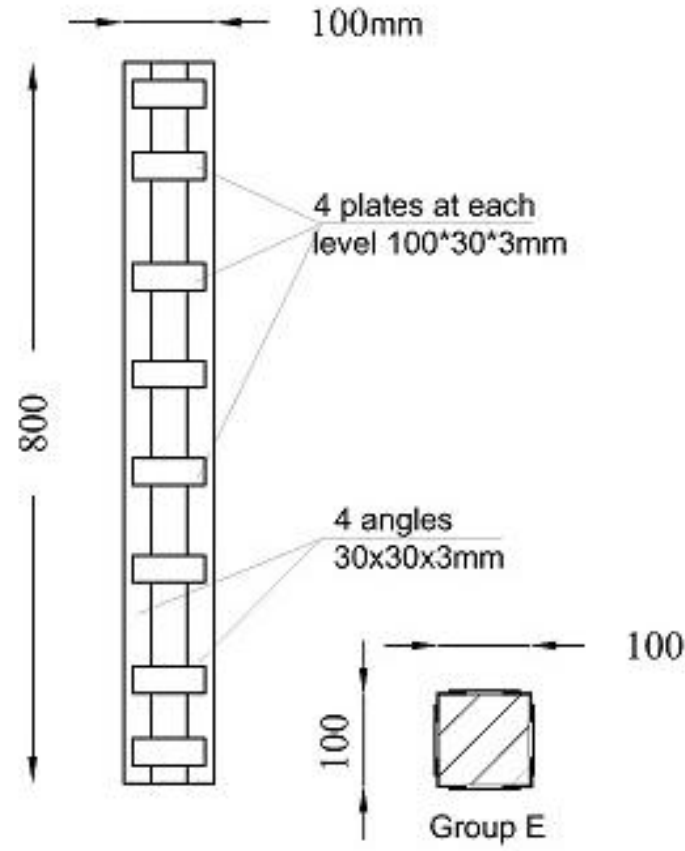

\subsection{Materials}

\subsubsection{Concrete}

Concrete with strength $36 \mathrm{MPa}$ was cast using materials from local market. Preparation of specimens was carried out in a way close to that commonly practiced in Field. Cement used is O.P.C. with grade 52.5, coarse aggregate is crushed dolomite and fine aggregate is sand. Potable water is used in mixing and curing. Chemical admixture was used to improve workability and made the concrete self compacted concrete. Mix proportions of concrete are shown in table (4).

Fig.1f Specimens details of group (E)

Table 4 Mix proportions of concrete for one cubic meter

\begin{tabular}{|c|c|c|c|}
\hline Cement $\left(\mathrm{Kg} / \mathrm{m}^{3}\right)$ & Water $\left(\mathrm{Kg} / \mathrm{m}^{3}\right)$ & Crushed dolomite $\left(\mathrm{kg} / \mathrm{m}^{3}\right)$ & Sand $\left(\mathrm{Kg} / \mathrm{m}^{3}\right)$ \\
\hline 325 & 220 & 1120 & 640 \\
\hline
\end{tabular}

\subsubsection{Mortar}

Mortar with strength $25.9 \mathrm{MPa}$ was cast using materials from local market. Preparation of specimens was carried out in a way close to that commonly practiced in Field. Cement used is O.P.C. with grade 42.5 and fine aggregate is sand. Potable water is used in mixing and curing. Chemical admixture was used to improve workability and made the mortar self-compacted concrete. The components of mortar was designed so that cement / sand ratio 1: 3 and the water cement ratio was 0.5

Table 5.Mechnical properties of concrete and mortar

\begin{tabular}{|c|c|c|}
\hline & $\begin{array}{c}\text { Original } \\
\text { column } \\
\text { (Core) }\end{array}$ & $\begin{array}{c}\text { Concrete } \\
\text { jacket } \\
\text { (mortar) }\end{array}$ \\
\hline $\begin{array}{c}\text { Average Cube } \\
\text { strength } \\
(\mathrm{MPa})\end{array}$ & 36 & 25.9 \\
\hline
\end{tabular}

\subsubsection{Steel}

Mild steel is used in vertical and high strength steel is used in lateral reinforcement of the column and in the jacket. The external steel angles used in steel jackets are mild steel. Materials properties were tested according to standard specifications and results are shown in Table 6.

Table 6.Mechanical properties of steel

\begin{tabular}{|c|c|c|c|}
\hline $\begin{array}{c}\text { Nominal } \\
\text { diameter } \\
(\mathrm{mm})\end{array}$ & $\begin{array}{c}\text { Average } \\
\text { yield } \\
\text { stress(MPa) }\end{array}$ & $\begin{array}{c}\text { Average } \\
\text { tensile } \\
\text { stress } \\
(\mathrm{MPa})\end{array}$ & $\begin{array}{c}\text { Elongation } \\
(\%)\end{array}$ \\
\hline 4 & 461.8 & 652.9 & 6.25 \\
\hline 6 & 323 & 410.5 & 27 \\
\hline
\end{tabular}

\subsection{Specimens Preparation}

A rotating mixer was used to mix the concrete components, then the concrete was poured in the formworks in a vertical direction and the concrete was vibrated internally and externally. Cubes $150 \times 150 \times 150 \mathrm{~mm}$ were also cast to determine the compressive strength of the concrete. After pouring, the formwork was removed after 2 days while the specimens were cured for one week by water.

\subsection{Strengthening Procedures}


The specimens were prepared for strengthening 28 days after casting. The experimental program includes three specimens of original column (group O) before strengthening in additional to nine specimens (group A, B, C) of strengthened reinforced concrete column by concrete jacket and six specimens strengthened by steel jacket (group D, E).

\subsubsection{Concrete jacket}

Main reinforced steel and stirrups of concrete jacket were attached to original column (core) and were put into formworks as shown in Fig (2).

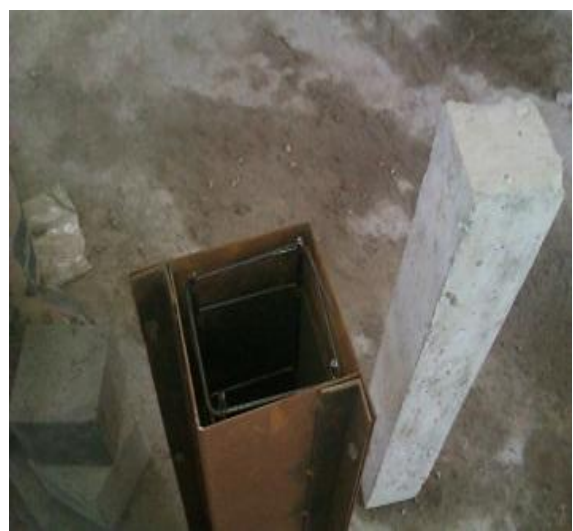

Fig.2 Concrete jacket before casting

The concrete was poured in the formworks in a vertical direction and the concrete was compacted. Cubes $150 \times 150 \times 150 \mathrm{~mm}$ were also cast to determine the compressive strength of the concrete as shown in Fig (3).



Fig.3 Concrete jacket after casting

\subsubsection{Steel cage}

A steel mould attached to the corner angles is used to translate the applied force to the corner angles. Steel plates were placed perpendicular the corner angles and welded to the angles after applying the force. The welding of plates with angles was left for short time to be cooled, and then the mould was removed.

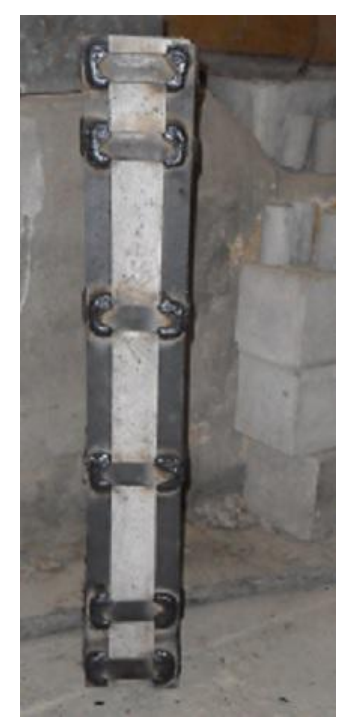

Fig.4 steel jacket

\subsection{Testing Procedures}

Before testing, Specimens were instrumented in such away to read axial forces. The columns were placed and adjusted between the heads of the machine base to prevent eccentricity of load. Columns were loaded gradually, where load records were taken. Tests were terminated when the load dropped to a low fraction of the maximum load reading, where a considerable damage was observed.

\section{THEORETICAL FORMULATION}

\section{Original Column (The core)}

The nominal ultimate load capacity of concrete sections subjected to axial force could be determined as:

$$
P_{u}=0.67 * f_{c u} * A_{c}+f_{y} * A_{s}
$$

Where

$P_{u} \quad$ Ultimate load of column

$f_{c u} \quad$ Compressive concrete strength

$A_{c} \quad$ Column cross section area

$f_{y} \quad$ Yielding strength of column main steel

As Area of column main steel cross section

Concrete jackets are the most popular methods of columns strengthening. In these types of jackets, additional vertical bars and stirrups are used. Efficiency of this method is affected by many parameters such as; jacket thickness, transverse reinforcement of jacket, jacket height, jacket strength, contact surface between the original column and jacket, and shear connectors. Strengthened column behaviour is also affected by concrete strength, stress level, rectangularity ratio, and vertical reinforcement. 
Taha, A.H [1] applied the first principles methods to put the following equations for calculating the ultimate load of the strengthened square column:

$P_{u}=4 * w_{1} * L+4 * w_{2} * L * n$

Where

$\mathrm{w}_{1} \quad$ confinement pressure at strip 1

$\mathrm{w}_{2} \quad$ confinement pressure at strip 2

L original column width

n number of strips

On the other hand, Steel jackets represent also a favourite strengthening technique. The method involves the use of longitudinal angle sections fixed to the corners of the column, to which transverse steel stirrups are welded. The space between cage and column is filled with cement or epoxy mortar. Using steel jackets increase the confinement, capacities, ductility and stiffness. Steel jackets have also advantages due to their light weight and don't cause significant increase in cross sectional area of the column compared to concrete jackets.

The ultimate load of the strengthened column can be expressed as [4]:

$P_{u}=0.85 * A_{c} * f_{c}+A_{s} * f_{y s}+K * f_{l} * A c+N_{L}$

Where

$N_{L}=N_{0} *\left(1-e^{-m s}\right)$

$m=\frac{\mu \cdot 4 \cdot v_{c}}{b \cdot\left(1-v_{c}+\frac{b \cdot E_{c}}{2 \cdot e_{s t} \cdot E_{L}}\right)}$

$\mathrm{K}$ is a parameter that makes allowance for the higher compressive strength of the concrete due to confinement pressure $f_{l}$

$\mathrm{P}_{\mathrm{u}}$ is the ultimate load of the strengthened column

$\mathrm{A}_{\mathrm{c}} \quad$ cross-section area of concrete

As cross-section area of steel angles

$\mathrm{f}_{1} \quad$ confinement pressure

$f_{y s} \quad$ yield stress of reinforcement steel

$f_{c} \quad$ compressive strength of concrete

$\mathrm{N}_{0}$ axial load supported by the concrete at the beginning of a strip

$\mathrm{N}_{\mathrm{L}} \quad$ axial load supported by the cage at end of strip

\section{EXPERIMENTAL RESULTS}

Three specimens of each group were used to evaluate column strength. The ultimate load of column was the average value of the three specimens' capacity. Figures from 5 to 11 show the failure of strengthened columns.



Fig.5 Original column failure



Fig.6 Jacket failure of group (A)



Fig.7 Jacket failure of group (B) 


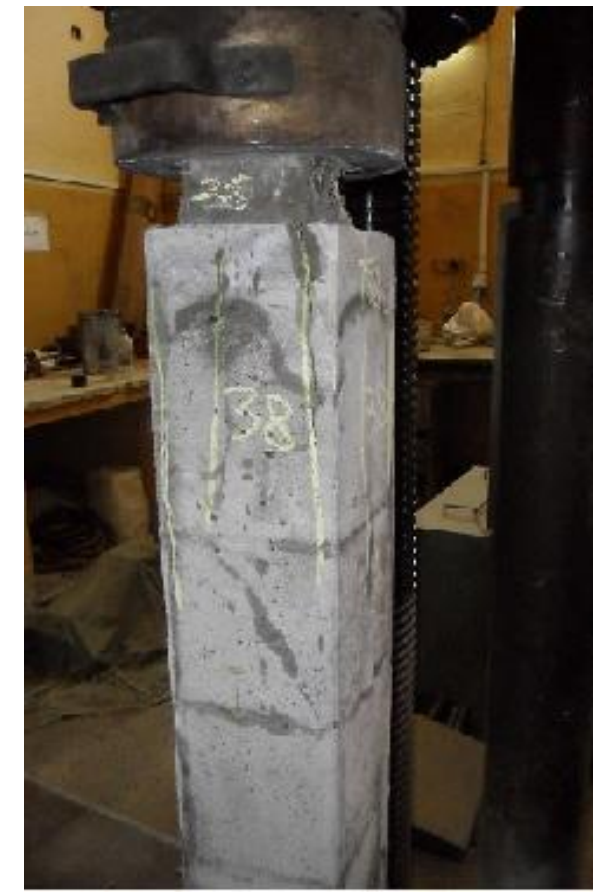

Fig.8 Jacket failure of group (C)

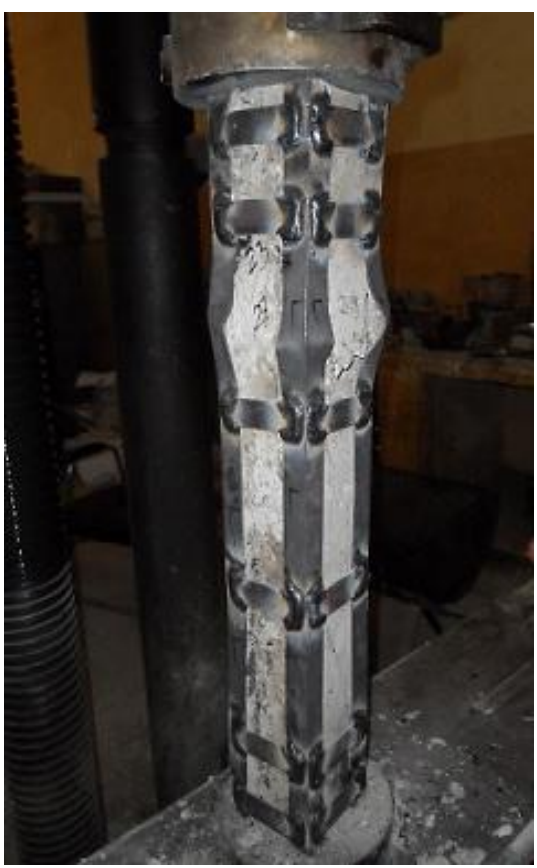

Fig.9 Jacket failure of group (D)



Fig.10 Jacket failure of group (D")



Fig.11 Jacket failure of group (E) 
Experimental and theoretical results of strengthened columns were illustrated in table 7

Table7 Experimental and theoretical results of jackets

\begin{tabular}{|c|c|c|c|c|c|c|c|}
\hline $\begin{array}{c}\text { Strengthening } \\
\text { type }\end{array}$ & 节 & $\begin{array}{c}\text { Specimen } \\
\text { number }\end{array}$ & $\begin{array}{c}\text { Maximum } \\
\text { capacity } \\
(\mathrm{KN})\end{array}$ & $\begin{array}{c}\text { Experimental } \\
\text { average } \\
\text { maximum } \\
\text { capacity } \\
(\mathrm{KN})\end{array}$ & 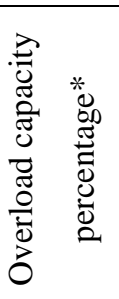 & $\begin{array}{c}\text { Analytical } \\
\text { capacity** } \\
(\mathrm{KN})\end{array}$ & $\frac{P_{u \text { experimental }}}{P_{\text {uanalyticd }}}$ \\
\hline \multirow{3}{*}{$\begin{array}{c}\text { Original } \\
\text { column (core) }\end{array}$} & \multirow{3}{*}{$\mathrm{O}$} & 1 & 249 & \multirow{3}{*}{253.3} & \multirow{3}{*}{$0 \%$} & \multirow{3}{*}{$\begin{array}{l}277.7 \\
\text { Eq.(1) }\end{array}$} & \multirow{3}{*}{0.91} \\
\hline & & 2 & 239 & & & & \\
\hline & & 3 & 272 & & & & \\
\hline \multirow{9}{*}{$\begin{array}{c}\text { Concrete } \\
\text { jacket }\end{array}$} & \multirow{3}{*}{ A } & 4 & 464 & \multirow{3}{*}{446.6} & \multirow{3}{*}{$76.3 \%$} & \multirow{3}{*}{$\begin{array}{l}373.7 \\
\text { Eq.(2) }\end{array}$} & \multirow{3}{*}{1.2} \\
\hline & & 5 & 424 & & & & \\
\hline & & 6 & 452 & & & & \\
\hline & \multirow{3}{*}{ B } & 7 & 472 & \multirow{3}{*}{473.3} & \multirow{3}{*}{$86.9 \%$} & \multirow{3}{*}{$\begin{array}{c}392 \\
\text { Eq.(2) }\end{array}$} & \multirow{3}{*}{1.2} \\
\hline & & 8 & 481 & & & & \\
\hline & & 9 & 467 & & & & \\
\hline & \multirow{3}{*}{$\mathrm{C}$} & 10 & 380 & \multirow{3}{*}{382} & \multirow{3}{*}{$50.8 \%$} & \multirow{3}{*}{$\begin{array}{l}368.8 \\
\text { Eq.(2) }\end{array}$} & \multirow{3}{*}{1.03} \\
\hline & & 11 & 384 & & & & \\
\hline & & 12 & 382 & & & & \\
\hline \multirow{7}{*}{$\begin{array}{c}\text { Steel jacket } \\
\text { (cage) }\end{array}$} & \multirow{3}{*}{$\mathrm{D}$} & 13 & 235 & \multirow{3}{*}{264.7} & \multirow{3}{*}{$4.5 \%$} & \multirow{3}{*}{$\begin{array}{l}386.6 \\
\text { Eq.(3) }\end{array}$} & \multirow{3}{*}{0.68} \\
\hline & & 14 & 295 & & & & \\
\hline & & 15 & 264 & & & & \\
\hline & D" & D" & 340 & 340 & $22.4 \%$ & $\begin{array}{c}346 \\
\text { Eq.(3) }\end{array}$ & 0.98 \\
\hline & \multirow{3}{*}{$\mathrm{E}$} & 16 & 453 & \multirow{3}{*}{465.7} & \multirow{3}{*}{$24.4 \%$} & \multirow{3}{*}{$\begin{array}{l}464.8 \\
\text { Eq.(3) }\end{array}$} & \multirow{3}{*}{1} \\
\hline & & 17 & 548 & & & & \\
\hline & & 18 & 396 & & & & \\
\hline
\end{tabular}

Remarks:

* Overload capacity $=\frac{P_{u j}-P_{u}}{P_{u}}$

Where $P_{u j}=$ column capacity after strengthening

$\mathrm{P}_{\mathrm{u}}=$ column capacity before strengthening

$\mathrm{P}_{\text {uexperimental. }}=$ Experimental capacity of strengthening column

$\mathrm{P}_{\text {uanalytical }}=$ Analytical capacity of strengthening column

** Equations (were used to calculate analytical capacity) were taken from part (3) theoretical formulation at this paper.

\section{RESULTS AND DISCUSSION}

Stirrups were distributed regularly along the column length. During the test, it was observed that column's full capacity wasn't reached because the column failure was noticed at column's base before 
reaching the full capacity of the column. So, Stirrups were intensified at upper and lower parts of original column.

For group (A), the concrete jackets had the same length and stirrups of the original column. The over load capacity of the strengthened column increased up to $76.3 \%$ of the original column capacity.

Stirrups of concrete jacket were intensified to increase the over load capacity of strengthened columns for group (B) which leads to an increase of capacity up to $87 \%$ of the original column.

The jacket of strengthened column in group (C) and (A) was nearly the same except the length of the jackets in group (C) was shorter than the original column length. The over load capacity of strengthened column increased up to $51 \%$ of the original column capacity.

The concrete jacket of group (B) showed the best results of strengthening because the jacket caused more confinement than jackets of group (A) and (C).

For group (D), Stirrup at steel jacket consists of four plates welded to jacket angles. The distances among stirrups (angle length) were nearly buckling length of the angles and the length of steel jacket and the original column was the same so the capacity of strengthened column increased to carry a very small amount of overload nearly $4.5 \%$ of the original column capacity before angle's buckling happened.

Stirrups of steel jacket for group D and D" were the same, but its distribution wasn't the same. Steel jacket for group D has been improved by making the jacket shorter than the original column and decreased the distances between stirrups. The over load capacity of strengthened columns for group (D") increased up to $22.4 \%$ of the original column capacity.

Stirrups of steel jacket were intensified to increase the confinement in the column. The over load capacity of strengthened columns in group (E) increased up to $24.4 \%$ of the original column capacity.

The steel jacket of group (E) had the best results of strengthening because the jacket caused more confinement for original column than the jacket for group D", and the jacket is more effective than the jacket for group D because the jacket for group $\mathrm{E}$ is shorter than the original column and this led to make the jacket effective for longer time before the angles buckling happened.

\section{CONCLUSION}

After studying the experimental and analytical results of strengthening column using concrete and steel jackets, the following conclusions were obtained:

1. For steel jacket: the length of cage's angles should be shorter than original column's length to achieve the benefit of cage. If the length of cage angles is equal to column length, the applied load will transmit to the angles as a vertical load and this lead to angle yielding by buckling and cause failure before benefiting of cage confinement.

2. For concrete jacket: the length of concrete jacket should be equal to the original column's length if possible to achieve the best benefit of the concrete jacket. If the length of concrete jacket is equal to the length of the column, part of the applied load will be transmitted to the jacket as a vertical load and the capacity of original column will increase up to $87 \%$ of the original column capacity by confinement.

3. The stirrups at upper and lower part of the concrete jacket should be intensified to a distance of (1-1.5) the jacket width.

4. The efficiency of jacket will be increased by decreasing the distance between stirrups.

5. Release of applied loads before jacketing increase the efficiency of the jacketed column up to $90 \%$.

6. Reinforced concrete jacket enjoys advantages in the form of economy, compatibility with the original column's concrete, and the ability to enhance durability and impart fire protection.

7. Using steel jackets increase the confinement, capacities, ductility and stiffness. Steel jackets have also advantages due to its light weight, besides they don't cause significant increase in cross sectional area of the column compared to concrete jackets.

\section{Reference}

[1] Taha, A.H. (2004), "New structural model for reinforced concrete jackets", Almarqb University, faculty of Engineering, Libya, Second national Conference for Construction materials and Structural Engineering, pp.50-60

[2] Adam J. M., Ivorra S., Giménez E., Moragues J. J., Miguel P., Miragall C., Calderon P.A. (2007), "Behavior of axially loaded RC columns strengthened by steel angles and strips", Steel Composite Structure, Volume 7, No. 5, pp. 405419.

[3] The Egyptian code for design and construction of concrete structure, (2007), No.203, Housing and Building Research Center, Dukki, Giza, Egypt.

[4] Adam J. M., Ivorra S., Giménez E., Moragues J. J., Miguel P., Miragall C., Calderon P.A. (2007), "Behavior of axially loaded RC columns strengthened by steel angles and strips", Steel Composite Structure, Volume 7, No. 5, pp. 405419.

[5] Jose M. Adam, Salvador Ivorra, Francisco J. Pallarés, Ester Giménez, and Pedro A. Calderon (2009), " Axially loaded RC columns strengthened by steel caging finite element modeling", Construction and Building Materials, Volume 23, pp. 2265-2276.

[6] Pedro A. Calderon, Jose M. Adam, Salvador Ivorra , Francisco J. Pallarés , Ester Giménez (2009), " 
Design strength of axially loaded RC columns strengthened by steel caging", Materials and Design, Volume 30, pp. 4069-4080. 